\title{
Sermaye Yapısının Belirleyicileri: İMKB'de İşlem Gören Çimento, Otomotiv ve Bilişim Sektörlerinin Sermaye Yapısı Analizi
}

\author{
Determinants of Capital Structure: A Study of the ISE Firms Operating in Cement, \\ Automotive and Information Technology Industries
}

Serra Eren SARIOĞLU1', Engin KURUN² ${ }^{2}$ Harun GÜZELDERE ${ }^{3}$

\begin{abstract}
ÖZET
Bu çalışmanın amacı, hisse senetleri IMKB'de işlem gören ve çimento, otomotiv ve otomotiv yan sanayi ve bilişim sektörlerinde faaliyet gösteren şirketlerin sermaye yapısı kararlarını etkileyen faktörlerin 2007-2011 dönemi için belirlenmesi ve sermaye yapısı kararlarında sektörler arası farklılıkların ortaya konmasıdır. Şirketlerin 2007-2011 yıllarına ait yılsonu finansal tablolarından derlenen finansal oranlarla panel veri analizleri uygulanmıştır. Oluşturulan modellerdeki bağımlı/bağımsız değişkenler sırasıyla finansal kaldıraç oranları ile şirketlerin kârlılık, büyüklük, varlık yapısı, likidite, borç dışı vergi kalkanı ve büyüme oranıdır. Analiz bulguları, uzun vadeli borçların toplam aktiflere oranına göre çimento ve otomotiv sektöründe anlamlı bir ilişki bulunmadığını göstermektedir. Bilişim sektöründe ise büyüklük ve varlık yapısı şirketlerin sermaye yapısını pozitif yönde etkilemektedir ve bu bulgu, sermaye yapısı teorilerine uygun bir bulgudur. Diğer yandan, çimento ve bilişim sektörlerinde şirket büyüklüğü toplam borçların toplam aktiflere oranını pozitif yönde etkilemektedir. Bu bulgudan hareketle, incelenen dönemde çimento ve bilişim sektörlerinde dengeleme kuramının geçerli olduğunu söylemek mümkündür. Bununla birlikte, sermaye yapısı teorilerine uygun bir bulgu olarak kaydedilmek üzere, otomotiv ve bilişim sektörlerinde büyümenin katsayısı istatistikî açıdan anlamlı ve pozitif bulunmuştur. Bu araştırmanın bulguları, Türkiye'de incelenen dönemde ve sektörlerde sermaye yapısı teorileri ile uyumlu bir yapının olduğunu ve sektörler arasında sermaye yapısı kararlarında farklılıklar bulunduğunu ortaya koymaktadır.
\end{abstract}

Anahtar Kelimeler: Sermaye yapısı, dengeleme kuramı, IMKB, çimento, otomotiv, bilişim

\section{GiRiş}

Bu çalışmanın amacı Türkiye'de çimento, otomotiv ve otomotiv yan sanayi ile bilişim sektörlerinde faaliyet göstermekte olan ve hisse senetleri IMKB'de işlem gören şirketlerin sermaye yapılarını belirleyen faktörlerin tespit edilmesidir. Çalışmanın tamamında otomotiv sektörü olarak ifade edilen sektör aslında otomotiv ve otomotiv yan sanayi şirketlerini içermek-

\begin{abstract}
The main purpose of this study is to determine the factors affecting the capital structures of cement, automotive and information technology firms traded in Istanbul Stock Exchange and to expose the industrial differences in the capital structures of the firms for the period 2007-2011. The financial ratios calculated from the financial tables of the firms are used in the panel data analysis of this study. In the research models, the dependent variables are the leverage ratios of the selected firms. Profitability and liquidity ratios and firm size, asset tangibility, growth rate and non-debt tax shield are assigned as independent variables. According to the empirical findings, there is no significant relation between long-term debt ratios and any independent variables in the cement and automotive industries. However, firm size and asset tangibility are found to be significant in explaining the long-term debt structure of information technology firms. Debt ratio is positively related to firm size both in the cement and information technology industries, which gives support to trade-off theory. Besides, debt ratio is positively related to growth rate both in the information technology and automotive industry in accordance with the capital structure theory. Consequently, the results show that the debt ratio sensitivities of the Turkish firms to the explanatory variables differ significantly between the three industries studied.
\end{abstract}

Keywords: Capital structure, trade-off theory, ISE, cement, automotive, information technology.

tedir. Araştırma 2007-2011 dönemini kapsamaktadır ve panel veri analizi kullanılarak gerçekleştirilmiştir.

Türkiye'de önceki yıllarda sermaye yapısına ilişkin yapılan çalışmalar şirketleri ağırlıklı olarak ana faaliyet kollarına (mali, sanayi, hizmet) veya iktisadi faaliyet kollarına (tarım, madencilik, imalat sanayi vb.) göre incelemiş, bunların alt bileşenlerine ilişkin karşılaştırmalı bir çalışma ortaya konulmamıştır. Bu çalışma- 
nın daha önceki benzerlerinden en önemli farkı, alt sektörler temelinde sermaye yapısı kararlarının tespit edilmeye çalışılması ve sermaye yapısında sektörel farklılıkların ve bu farklııkları oluşturan nedenlerin araştırılmasıdır. Ayrıca bu genel bakış açısının dışında, daha önceki çalışmalarda bulunan ilişkilerin incelenen dönemde devam edip etmediği de bu çalışmanın konusunu oluşturmaktadır. Çimento ve bilişim sektörlerinin seçilmesinin nedeni, bildiğimiz kadarıyla bu sektörlerde faaliyet gösteren Türk şirketlerinin sermaye yapılarını araştıran herhangi bir çalışmanın bulunmamasıdır.

Analize konu sektörler Türkiye'de son yıllarda öne çıkan ve büyümeye doğrudan katkı yapan sektörlerden seçilmiştir. Taş-toprak sektörü altında veya imalat sanayi altında değerlendirilen çimento sektörünün $15 \mathrm{Kasım}$ 2012 tarihi itibarıyla 505 milyar TL tutarındaki IMKB toplam piyasa kapitalizasyonu içinde payı yaklaşık 10 milyar TL (\%2)'dir. IMKB'de banka, sigorta, yatırım ve holding hisse senetlerinin $\% 53$, hizmet sektörünün $\% 20$, sanayi sektörünün \%27 ağırlığa sahip olması nedeniyle, bu oranı sanayi sektörü için hesapladığımızda, incelemeye konu çimento sektörünün payı \%8'e yükselmektedir. Otomotiv sektörü, sağladığı ekonomik katkı oranı ile imalat sanayi içinde Türkiye'nin önde gelen sektörleri arasında yer almaktadır. Sanayi sektörü içinde piyasa kapitalizasyonu bakımından yaklaşık 17 milyar TL ile (\%13) metal eşya, makina, kimya petrol kauçuk ve metal ana sektörlerinde faaliyet gösteren şirketlerden oluşmaktadır. Sektör, özellikle 1990'lı yılların başında hızıı bir gelişim içine girmiştir. Türkiye, 2011 yılında dünya motorlu araç üretiminde on yedinci, Avrupa Birliği üretiminde ise altıncı sırada yer almıştır. Sektör ayrıca, 2011 yııında 135 milyar dolarlık toplam inracat içindeki \%15'lik payı ile en önde gelen sektör olarak dikkat çekmektedir. Otomotiv sektörünün ilgili dönemde 20 milyar dolar döviz kazandırıcı etkisi bulunmaktadır. Otomotiv sektörünün çalışma kapsamına alınmasının en önemli nedeni, bu sektörün yerli yan sanayi KOBI şirketleri ile birlikte Türk Ekonomisi'nde oldukça önemli bir yere sahip olmasıdır. Bilişim sektörü, hizmetler sektörü içinde ağırlığı giderek artan ve yüksek büyüme hızıyla yıllar itibariyle IMKB'de halka arzların yoğunlaştığı bir sektör olarak öne çıkmaktadır. Seçilen şirketlerin hizmet sektörü piyasa kapitalizasyonu içindeki payı 1,5 milyar TL ile yaklaşık \% 2'dir. Teknoloji ana sektörü içinde ise bilişim, teknoloji perakende ve telekom sektörleri yer almaktadır. Teknoloji sektörünün hizmet sektörü piyasa kapitalizasyonu içindeki payı ise 49 milyar TL ile yaklaşık \% 50'dir.

Bu çalışmanın finans literatürüne temel katkısı, yukarıda belirtilen sebeplerle literatürdeki mevcut boşluğu doldurmak ve sektörler arası sermaye yapılarının farklılığını ortaya koymak olarak özetlenebilir.

\section{LITERATÜR TARAMASI}

Günümüzde modern sermaye yapısı kuramları temelde iki başlık altında incelenmektedir: Bunlardan ilki dengeleme kuramı diğeri ise finansal hiyerarşi kuramıdır. Birçok araştırmacı, her iki kuramın işletmelere özgü geçerli olduğu koşulları incelemiş ve bu konuda çok sayıda akademik çalışma yapılmıştır. Bu bölümde ilgili kuramların temel özellikleri açıklandıktan sonra, gelişmekte olan ülkelerde ve ülkemizde yapılan çalışmalar değerlendirilmiştir.

Modigliani ve Miller (1958) tarafından ilk kez gündeme getirilen sermaye yapısı kuramı, etkin piyasa koşullarında ve vergisiz ortam varsayımıyla sermaye yapısının şirketlerin piyasa değeri üzerinde bir etkisinin olmayacağını, dolayısıyla sermaye-borç ilişkisi kullanılarak piyasa değerinin maksimize edilemeyeceğini ileri sürmüştür. Bu husus literatüre "ilintisizlik kuramı" olarak geçmiştir. Ilerleyen zamanda vergi faktörü, iflas ve temsilci maliyetleri, asimetrik bilgi faktörlerini de içeren çalışmalar yapılmıştır. Modigliani ve Miller (1963) tarafından daha sonra verginin sermaye yapısı üzerine etkisi araştırılmış, şirketlerin borçlanma karşılığı ödediği faizlerin vergiden düşülmesiyle finans literatürüne "vergi kalkanı" olarak geçen avantaj nedeniyle şirketlerin borçlanmayı tercih edeceği belirtilmiştir. Aynı bulgular Miller (1977), Taggart (1977), Pozdena (1987) ve Titman ve Wessels (1988), tarafından da desteklenmiştir.

Haugen ve Senbet (1978) şirketlerin borçla finansmanı tercih etmesi ve bu oranın artması halinde anapara ve faiz ödeme yükümlülüğünün yerine getirilmeme olasılığını iflas maliyeti olarak tanımlamış ve literatüre "finansal sıkıntı maliyetleri kuramı" olarak katkıda bulunmuştur. Harris ve Raviv (1991), De Angelo ve Masulis (1980), Stiglitz (1988), Brigham ve Houston (1999) da benzer bulgular ile kuramı desteklemiştir. Ross (1977) şirket yöneticileri ile şirket dışındaki kişilerin şirket ile ilgili sahip oldukları bilgi düzeylerindeki farklılığa dikkat çekerek, şirket dışındakilerin şirketin sermaye yapısı tercihlerine göre şirket değerini tahmin etmeye çalıştıklarını ileri sürmüştür. Literatüre "asimetrik bilgi" kuramı olarak geçen bu çalışmaya benzer konuda Myers ve Majluf (1984), Leland ve Pyle (1977), Harris ve Raviv (1991), Gitman (2003), Chen (2004) çalışmalar üretmiştir. Jensen ve Meckling (1976) şirket yöneticileri, hissedarlar ve işletmeye borç verenler (şirket tahvili alanlar) arasındaki çıkar çatışmalarından yola çıkarak literatüre "temsilci maliyetleri kuramı" olarak geçen ilişkiyi incelemiştir. Fama (1980), Stulz (1990), Harris ve Raviv (1991) temsilciler arasındaki çıkar çatışmalarını araştırmışlardır. Kraus ve Litzenberger (1973) şirketlerin optimal sermaye yapısı belirlenirken vergi kalkanından elde edilen avantaj ile 
iflas ve temsilci maliyetlerinin dengelenmesi gereğini ileri sürmüşlerdir. Literatürde "dengeleme kuramı" olarak kabul edilen bu görüşü destekleyici diğer çalışmalar Kim (1978), Myers (1984) tarafından yapılmıștır.

Finansman hiyerarşisi kuramı ilk kez Myers ve Majluf (1984) tarafından gündeme getirilmiştir. Buna göre yatırımların finansmanında şirketler öncelikli olarak iç kaynaklar (özsermaye) daha sonra ise dış kaynaklara (borçlanma) başvurmaktadır. Hisse senedi ihracı ile finansman ise tercih edilen en son seçenektir. Rajan ve Zingales (1995), Fama ve French (2002), Frank ve Goyal (2003) kuramı geliştiren diğer çalışmaları gerçekleştirmişlerdir.

Gelişmekte olan ülkelerde yapılan çalışmalarda sermaye yapısının hangi kurama göre belirlendiğine ilişkin çeşitli bulgular mevcuttur. Clark, Francis ve Hasan (2009) dengeleme kuramının hem gelişmiş hem de gelişmekte olan ülkelerde geçerli olduğunu 40 ülke için ortaya koymuştur. Ismail ve Eldomiaty (2005) bulguları ise Mısır için finansal hiyerarşi kuramının geçerli olduğunu ortaya koymuştur. De Mederios ve Daher (2005) Brezilya'da şirketlerde finansal hiyerarşi kuramının geçerli olduğunu belirtmişlerdir. Anwar (2012) Pakistan'da Karaçi Borsası'nda işlem gören tekstil, çimento ve enerji sektörlerinden toplam 199 şirketin sermaye yapısını incelemiştir ve finansman hiyerarşisi kuramının geçerliliğini vurgularken sektörler arası farklıılıları ortaya koymuştur. Crnigoj ve Mramor (2009) Slovenya'daki, Colombo (2001) Macaristan'daki, Deesomsak, Paudyal ve Pescetto (2004) Tayland, Malezya, Singapur ve Avustralya'daki şirketler için benzer çalışmaları yapmışlardır.

Durukan (1997b), iMKB'de işlem gören 68 şirketin sermaye yapısını belirleyen faktörleri 1990-1995 dönemi için kârlılık ve borç dışı vergi kalkanı olarak tespit etmiştir. Bu bulgular finansman hiyerarşisi kuramı ile örtüşmektedir. Okuyan ve Taşçı (2010), Türkiye'de sanayi şirketlerinin sermaye yapısını 1993-2007 dönemi için 1000 şirket üzerinde araştırmış ve finansman hiyerarşisi kuramını destekler bulgulara ulaşmıştır. Korkmaz, Başaran ve Gökbulut (2009), özellikli olarak IMKB'de işlem gören otomotiv ve yan sanayi şirketlerinin sermaye yapısını 2003-2006 döneminde incelemiş ve özsermaye kârlılığının ve borç dışı vergi kalkanının temel belirleyiciler olduğunu ve dolayısıyla finansman hiyerarşisine uygun sonuçlar elde ettiklerini vurgulamışlardır. Teker, Taşseven ve Tükel (2009), İMKB 100 Endeksi içinden 42 şirketin sermaye yapısını 20002007 döneminde incelemiş, aktif getirisinin ve maddi duran varlıkların kaldıraç oranını pozitif etkilediğini istatistikî açıdan anlamlı bulmuştur. Bu ilişki yazarlar tarafından dile getirilmese de finansman hiyararşi kuramını desteklemektedir. Topal (2006), İMKB imalat sanayi şirketlerinin sermaye yapısını 1997-2003 dönemi için incelemiş, sonuç olarak finansal kaldıraç oranı üzerinde aktif kârlılığının ve brüt kâr marjının etkisinin zayıf olduğunu bulmuştur. Güloğlu ve Bekçioğlu (2002), IMKB'de işlem gören en büyük 42 şirket için 1992-2000 dönemine ilişkin borç özsermaye yapısını kısa ve uzun vadeli borçları ayrıştırarak incelemiş ve borsadaki gelişmelerin kısa dönemde finansal kaldıraç imkânlarını olumlu etkilediğini bulmuştur. Güler (2010), 1996-2007 döneminde iMKB'de işlem gören 24 KOBI'nin sermaye yapılarını incelenmiş, bulgular KOBi'lerin finansman hiyerarşisi kuramına uygun hareket ettiği yönünde çıkmıştır. Demirhan (2009), IMKB'de işlem gören hizmet sektörü şirketlerinin 2003-2006 dönemindeki sermaye yapısını incelemiş ve finansman hiyerarşisine uygun sonuçlar elde etmiştir. Acaravcı (2004), IMKB'de işlem gören imalat sanayi şirketlerini 1992-2002 döneminde incelemiş ve şirketlerin sermaye yapısı ile büyüme oranı, kârııık, bankacilık sektörünün gelişmişliği, enflasyon ve kurumlar vergisi arasında anlamlı ilişkiler bulmuştur. Bu bulgular finansman hiyerarşisi kuramını destekler niteliktedir. Fıratoğlu (2005), IMKB'de işlem gören mali olmayan 196 şirketin kriz dönemindeki sermaye yapısını incelemiş, kriz dönemi olarak tanımlanan 1995 ve 1998'de iç kaynaklarla finansmana yönelmede artış gözlemlemiştir. Bu durum finansman hiyerarşisini destekler niteliktedir. Terim ve Kayalı (2009), IMKB imalat sanayi şirketlerinin 2000-2007 döneminde sermaye yapısını incelemiş ve finansman hiyerarşisi kuramını destekleyen bulgulara ulaşmıştır. Yükeri (2009), önceki çalışmaların aksine yüksek lisans tez çalışmasında borsa dışından şirketleri ele almış; Adana Hacı Sabancı Organize Sanayi Bölgesindeki 112 şirkete uygulanan anket sonuçlarına göre şirketlerin sermaye yapılarının finansman hiyerarşi kuramına uygun olduğu sonucuna ulaşmıştır. Ata (2010), IMKB'de kayıtlı metal ana sanayi ve metal eşya, makine ve gereç yapım sektörlerinden 42 şirketin 2003-2007 döneminde sermaye yapısını incelemiş ve finansman hiyerarşisi kuramını destekleyici sonuçlar elde etmiştir.

\section{FARKLI SEKTÖRLERDEN ŞIRKETLERIN SERMAYEYAPISI KARARLARINIETKILEYEN FAKTÖRLERIN BELIRLENMESINE YÖNELIK BíR ARAŞTIRMA}

\subsection{Araștırmanın Amacı ve Kapsamı}

$\mathrm{Bu}$ araştırmanın amacl, hisse senetleri IMKB'de işlem gören ve üç ayrı sektörde faaliyet gösteren şirketlerin sermaye yapısı kararlarını etkileyen faktörlerin 2007-2011 dönemi için belirlenmesi ve sermaye yapısı kararlarında sektörler arası farklılıkların ortaya konmasıdır. Çalışmanın kapsamına çimento, otomotiv ve bilişim sektörlerinde faaliyet gösteren şirketler alınmıştır. 


\subsection{Veri Seti ve Kısıtlar}

Araştırmada hisse senetleri iMKB'de işlem gören ve 2007-2011 yılları arasında verileri süreklilik arz eden çimento sektörüne ait 15 adet şirket, otomotiv sektörüne ait 15 adet şirket ve bilişim sektörüne ait 12 adet şirket ele alınmıştır. Bu şirketler alfabetik sırayla aşağıda Tablo 1'de yer almaktadır. Şirketlerin sermaye yapılarını belirlemek amacıyla kurulan modellerde şirketlere ait kullanılan oranlar, Kamuyu Aydınlatma Platformu'nun internet sitesinde (www.kap.gov.tr) yer alan şirketlerin 12 aylık finansal tablolarından ve bunların dipnotlarından yararlanılarak hesaplanmıştır. Ayrıca özellikle belirtmek gerekir ki, araştırma her bir sektör için ayrı ayrı yapılmış, çalışma kapsamında yer alan her bir sektörün sermaye yapısı belirleyicilerini ayrı ayrı tespit edebilmek amaçlanmıştır. Bu noktadan hareketle, çimento ile otomotiv sektöründe 75 'er adet, bilişim sektöründe ise 60 adet gözlem sayısı bulunmaktadır. Verisine ulaşılamayan şirketler kapsam dışında bırakılmıştır.

Tablo 1: Araştırma Kapsamında Yer Alan Şirketler

\begin{tabular}{|l|l|l|l|l|l|}
\hline \multicolumn{1}{|c|}{ Şirketin Adı } & \multicolumn{1}{c|}{$\begin{array}{c}\text { Şirketin } \\
\text { Kodu }\end{array}$} & \multicolumn{1}{c|}{$\begin{array}{c}\text { Şirketin Adı } \\
\text { Kodu } \\
\text { Kodinetin }\end{array}$} & \multicolumn{1}{c|}{$\begin{array}{c}\text { Şirketin Adı } \\
\text { Çimento Otomotiv }\end{array}$} \\
\hline Adana Çimento & ADANA & Anadolu Isuzu & ASUZU & Alcatel Lucent Teletaş & ALCTL \\
\hline Afyon Çimento & AFYON & Ditaş Doğan & DITAS & Anel Telekom \\
\hline Akçansa & AKCNS & Ford Otosan & FROTO & Arena Bilgisayar \\
\hline Batı Çimento & BTCIM & Otokar & OTKAR & Armada Bilgisayar \\
\hline Batısöke Çimento & BSOKE & Tofaş & TOASO & Datagate Bilgisayar \\
\hline Bolu Çimento & BOLUC & Bosch Fren Sistemleri & BFREN & Escort Teknoloji \\
\hline Bursa Çimento & BUCIM & Brisa & BRISA & Indeks Bilgisayar \\
\hline Çimbeton & CMBTN & Çelik Halat & CELHA & Karel Elektronik \\
\hline Çimentaş & CEMTS & Çemtaş & CEMTS & Link Bilgisayar \\
\hline Çimsa & CIMSA & Demisaş Döküm & DMSAS & Logo Yazılım \\
\hline Göltaş Çimento & GOLTS & Döktaş & COMDO & Netaş Telekom \\
\hline Konya Çimento & KONYA & Ege Endüstri & EGEEN & Plastikkart \\
\hline Mardin Çimento & MRDIN & F-M Piston & FMIZP & & KAREL \\
\hline Nuh Çimento & NUHCM & Good Year & GOODY & & LINK \\
\hline Ünye Çimento & UNYEC & Mutlu Akü & MUTLU & \\
\hline
\end{tabular}

\subsection{Araştırma Modelinin Geliştirilmesi}

Finans yazınında şirketlerin sermaye yapılarını etkileyen faktörlerin tespit edilmesine yönelik çok sayıda çalışma yapılmıştır (DeAngelo ve Masulis, 1980; Titman ve Wessels, 1988; Durukan, 1997b; Bhaduri, 2002; Huang ve Song, 2002; Yener, 2002; Cassar ve Holmes, 2003; Acaravcl, 2004; Chen, 2004; Akhtar, 2005; Sayılgan vd, 2006; Demirhan, 2009; Korkmaz, Başaran ve Gökbulut, 2009 vb). Araştırmanın modeli ve modelde kullanılan değişkenler, Korkmaz, Başaran ve Gökbulut (2009) referans alınarak oluşturulmuştur.

\subsubsection{Değişkenlerin Belirlenmesi}

Sermaye yapısı ile ilgili yapılmış önceki çalışmalarda araştırmacılar, şirketin sermaye yapısını temsil eden ve finansal kaldıraç oranları olarak bilinen oranları bağımlı değişken olarak kullanmışlardır. Bunlar genellikle, toplam borçların ve kısa ve uzun vadeli borçların ayrı ayrı olmak üzere özsermayeye ve toplam aktiflere oranından oluşan değişkenler olmuştur. Finans teorisinde sermaye yapısı, uzun vadeli borçların özsermayeye oranı olarak tanımlanmaktadır. Bunun nedeni, şirket politikalarında sermaye yatırımlarının (duran varlıkların) nasıl finanse edileceği, bir başka deyişle uzun vadeli borcun özsermayeye oranının nasıl olması gerektiği önemli bir yere sahiptir. Bu çalışmada da "uzun vadeli borçların toplam aktiflere oranı" sermaye yapısı oranı olarak kullanılmıştır. Ancak Türkiye'de sermaye yapısı içinde kısa vadeli borçların hiç de azımsanamayacak bir yere sahip olduğu düşünüldüğünde, bu çalışmanın ikinci bağımIı değişkeni olarak "toplam borçların toplam aktiflere" oranı hesaplanmıştır. Çalışmada kullanılan bağımsız değişkenler, sermaye yapısını araştıran çalışmalarda kullanılan değişkenler temel alınarak belirlenmiştir. Bunlar kârlıık, büyüklük, varlık yapısı, likidite, borç dışı vergi kalkanı ve büyüme oranıdır.

\subsubsection{Kârlılık}

Şirketlerin sermaye yapısı ile kârılıkları arasındaki ilişki teorik yaklaşımlara göre ele alındığında, tam olarak ne yönde bir ilişki olduğunu saptamak kolay değildir. Bu teorik yaklaşımlardan finansman hiyerarşisi kuramına göre şirketler, yatırımlarının finansmanında öncelikle iç fonlarını kullanmayı, daha sonra borçlanmayı ve son olarak yeni hisse senedi ihraç etmeyi tercih ederler. Bu nedenle bu kuram, kârlıığı yüksek olan işletmelerin daha az oranda borçlanacağını öne sürmektedir. Diğer yaklaşım olan dengeleme kura$\mathrm{m}$ ise, şirketin optimal sermaye yapısı belirlenirken borçlanmanın sağladığı vergi avantajı ile neden olduğu finansal sıkıntı ve temsilci maliyetleri arasında bir denge oluşturulması gerektiğini söylemektedir. 
Şirketin kârlıığı arttıkça faiz maliyetini taşıma kapasitesi artacaktır. Bir başka deyişle, borcun şirkete getirdiği dezavantajların etkisi azalacak ve şirketin optimal borçlanma düzeyi yükselecektir. Finansman hiyerarşisi kuramı kârlılığı yüksek olan şirketlerin daha az oranda borçlanacağını ileri sürerken, dengeleme kuramı borçlanma ile kârlılık arasında pozitif bir ilişki olduğunu öne sürmektedir. Bu çalışmada kârlılık ile borç seviyesi arasında pozitif bir iliş̧ki bulunması dengeleme kuramının, negatif bir ilişki bulunması ise finansman hiyerarşisi kuramının geçerli olduğu şeklinde yorumlanacaktır. Çalışmada kârlılık değişkeninin ölçüsü olarak aktif kârlılığı (faiz ve vergi öncesi kârın toplam aktiflere oranı) ve özsermaye kârlılığı (net kârın özsermayeye oranı) kullanılmıştır. Fakat değişkenler arasında yapılan korelasyon testi sonuçlarına göre incelenen üç sektörde de iki kârlılık ölçüsü arasında yüksek oranda korelasyon bulunmuştur (Her bir sektör için hazırlanan korelasyon matrisleri Ek 1'de yer almaktadır). Bu nedenle analizlere yalnız aktif kârlıığı dâhil edilmiştir.

\subsubsection{Büyüklük}

Şirketlerin kârlılıkları ile sermaye yapıları arasındaki ilişkide olduğu gibi, büyüklük ile sermaye yapısı arasındaki bağlantıda da finans teorisinde farklı görüşler bulunmaktadır. Bazı araştırmacılar, dengeleme kuramını savunarak, küçük şirketlerin daha yüksek risk içermelerinden dolayı daha düşük oranlarda borçlanacaklarını belirtmiştir (Titman ve Wessels, 1988). Bunun nedeni, küçük şirketlerin yüksek iflas riski nedeniyle optimal borçlanma düzeyleri daha düşüktür. Finansman hiyerarşisi kuramına göre ise, şirketin büyüklügü ile borçlanma düzeyi arasında negatif bir ilişki olmalıdır. Çünkü büyük şirketlerin iç fonlarının küçük şirketlere göre daha fazla olduğu varsayılmakta ve şirketlerin öncelikle bu fonları kullanacağı düşünülmektedir. Bu çalışmada büyüklük değişkeni ile borç seviyesi arasında pozitif bir ilişki bulunması dengeleme kuramının, negatif bir ilişki bulunması ise finansman hiyerarşisi kuramının geçerli olduğu şeklinde yorumlanacaktır. Araştırmada büyüklük değişkeninin ölçüsü olarak, analiz dönemindeki her sene için ayrı ayrı olmak üzere, her bir şirketin aktifinin faaliyet gösterdiği sektördeki şirketlerin toplam aktifleri içindeki oranı alınmıştır.

\subsubsection{Varlık Yapısı}

Şirketlerin maddi duran varlıkları ile borçluluk seviyeleri arasında pozitif bir ilişki olması beklenmektedir. Bunun nedeni, maddi duran varlıkların borç alırken teminat gösterilebilmesi, maddi duran varlıkları yüksek olan şirketlerin kredibilitelerinin yüksek olacağı ve daha yüksek oranlarda borç kullanabilecek olmalarıdır. Maddi teminat veremeyen şirketler yüksek faiz oranı ile borçlanmakta ve hatta bazen hiç borçlanamamaktadır. Bu noktadan hareketle denilebilir $\mathrm{ki}$, maddi duran varlıklar ile borçluluk düzeyi arasında pozitif bir ilişki bulunmalıdır (Sogorb-Mira, 2005; Chen, 2004; Akhtar, 2005; Sayılgan vd., 2006 ve Demirhan, 2009). Bu çalışmada varlık yapısı değişkeninin ölçüsü olarak şirketlerin maddi duran varlıklarının toplam varlıklarına oranı hesaplanmıştır.

\subsubsection{Likidite}

Finansman hiyerarşisi kuramına göre, likiditesi yüksek olan şirketler yatırımlarını bu likidite ile yapabildikleri için daha az borçlanmaktadır (Özkan, 2001; Demirhan 2009). Bununla birlikte yöneticiler, hissedarların lehine fakat alacaklıların aleyhine olmak üzere likit varlıkları kâr payı şeklinde dağıtarak borçlanmanın temsilcilik maliyetlerini arttırmaktadır. Bu nedenlerle, likidite ile borçluluk düzeyi arasında negatif bir ilişki olması beklentiler arasındadır (Deesomsak, Paudyal ve Pescetto 2004). Bu araştırmada likiditenin göstergesi olarak asit-test oranı (dönen varlıklar ile stoklar arasındaki farkın kısa vadeli borçlara oranı) kullanılmıştır.

\subsubsection{Borç Dışı Vergi Kalkanı}

Bilindiği gibi, borçla finansmanın sağladığı vergi avantajı kimi zaman şirketler için oldukça büyük önem arz etmektedir. Borcun faizinin dışında önemli bir vergi kalkanı aracı da amortismanlardır. Amortismanlar şirketler tarafından gider olarak yazılmakta ve vergi avantajı sağlamakta, bu anlamda da "borç dışı vergi kalkanı" olarak nitelendirilmektedir. Finans yazınında yapılan çalışmaların bir çoğunda borç dışı vergi kalkanı ile borçluluk düzeyi arasında negatif bir ilişki saptanmıştır (DeAngelo ve Masulis, 1980; Durukan, 1997b; Huang ve Song, 2002; Sayılgan vd., 2007). Bu bulgulardan farklı olarak Korkmaz vd (2007) KOBi'lerin borçluluk düzeyleriyle borç dışı vergi kalkanı arasında pozitif bir ilişki bulmuştur. Bu çalışmada da borç dışı vergi kalkanı ile borçluluk düzeyi arasında negatif bir ilişki olması beklenmektedir. Literatürdeki çalışmalar izlenerek bu çalışmada borç dışı vergi kalkanını temsilen amortisman giderlerinin toplam aktiflere oranı kullanılmıştır.

\subsubsection{Büyüme Oranı}

Şirketlerin büyüme oranları ile borçluluk yapıları arasında pozitif yönlü bir ilişki olduğu öne sürülmektedir. Büyüme oranları yüksek olan şirketlerin iç fonları, finansal ihtiyaçlarını karşılamak için yeterli olmayacaktır. Bu nedenle de bu şirketler borçlanmalarını arttıracaklardır (Titman ve Wessels, 1988; Bhaduri, 2002). Fakat Yener (2002) çalışmasında borçlanma düzeyi ile büyüme oranı arasında negatif bir ilişki tespit etmiştir. Bu çalışmada büyüme oranı olarak satışların yıllık 
yüzdesel büyüme oranı alınmıştır. Bu oran ilgili yıldaki enflasyon oranı ile düzeltilmiş ve reel büyüme oranlarına ulaşılmıştır. Aşağıda Tablo 2'de analizlerde kullanılan değişkenler, bu değişkenlerin nasıl hesaplandığı ve hangi çalışmaların referans alındığı özet olarak yer almaktadır.

\subsubsection{Araştırma Modeli}

Sermaye yapısıyla ilgili bağımlı ve bağımsız değişkenlerin tanımlanmasının ardından, sermaye yapısını belirleyen faktörleri tespit etmek amaciyla kurulan model aşağıda yer almaktadır. Bu model her bir sektör için ayrı ayrı oluşturulmuştur:

Tablo 2: Analizlerde Kullanılan Değişkenler

\begin{tabular}{|c|c|c|}
\hline Değişken & Kullanılan Oran & Referans \\
\hline Kârlılık (AK) & $\begin{array}{l}\text { Aktif Kârlılığı (Faiz ve Vergi Öncesi Kâr / Aktif } \\
\text { Toplamı) } \\
\text { Özsermaye Kârııı̆ı (Net Kâr /Özsermaye) }\end{array}$ & $\begin{array}{l}\text { Friend ve Lang (1988), Booth ve } \\
\text { diğerleri (2001), Deesomsak ve } \\
\text { diğerleri (2004), Huang ve Song (2006) }\end{array}$ \\
\hline Büyüklük (AB) & $\begin{array}{l}\text { Aktif Büyüklüğü (Şirketin Aktifi / Toplam } \\
\text { Aktifler) }\end{array}$ & $\begin{array}{l}\text { Friend ve Lang (1988), Deesomsak ve } \\
\text { diğerleri (2004) }\end{array}$ \\
\hline Varlık Yapısı (VY) & Maddi Duran Varlıklar / Toplam Aktifler & $\begin{array}{l}\text { Friend ve Lang (1988), Deesomsak ve } \\
\text { diğerleri (2004), Huang ve Song (2006) }\end{array}$ \\
\hline Likidite (ATO) & $\begin{array}{l}\text { Asit-Test Oranı (Dönen Varlıklar - Stoklar / Kısa } \\
\text { Vadeli Borçlar) }\end{array}$ & Korkmaz ve diğerleri (2009) \\
\hline $\begin{array}{l}\text { Borç Dışı Vergi Kalkanı } \\
\text { (BDVK) }\end{array}$ & Dönem Amortisman Gideri / Toplam Aktifler & $\begin{array}{l}\text { Titman ve Wessels (1988), Deesomsak } \\
\text { ve diğerleri (2004), Huang ve Song } \\
\text { (2006) }\end{array}$ \\
\hline Büyüme Oranı (BYM) & Satışların Yıllık Reel Büyüme Oranı & $\begin{array}{l}\text { Cassar ve Holmes (2003), Crnigoj ve } \\
\text { Mramor (2009) }\end{array}$ \\
\hline
\end{tabular}

$$
\begin{aligned}
Y_{i t}= & a_{i t}+\beta_{1} A K_{i t}+\beta_{2} A B_{i t}+\beta_{3} V Y_{i t}+\beta_{4} A T O_{i t}+ \\
& \beta_{5} B V K_{i t}+\beta_{6} B Y M_{i t}+\varepsilon_{i t} \\
& i=1, \ldots \ldots, N \quad t=1, \ldots \ldots ., T
\end{aligned}
$$

Modelde $Y_{i t^{\prime}}$ her bir sektör için borçluluk değişkenlerini (toplam borcun toplam aktife oranı -B notasyonu ile temsil edilmektedir - ve uzun vadeli borcun toplam aktife oranı - UVB notasyonu ile temsil edilmektedir), i şirketi, $t$ ise dönemleri temsil etmektedir. $\mathrm{N}$ toplam şirket sayısını gösterirken, $\mathrm{T}$ toplam dönem sayısını göstermektedir. $A K_{\text {it }}$ aktif kârlıı̆ı olarak ifade edilebilecek olan kârlılık değişkenini, $A B_{\text {it }}$ şirketin aktif yapısının büyüklüğünü, $V Y_{\text {it }}$ şrketin varlık yapısını (maddi duran varlıkların toplam aktifler içindeki payı), $\mathrm{ATO}_{\text {it }}$ şirketin likidite durumunu, BDVK ${ }_{\text {it }}$ borç dışı vergi

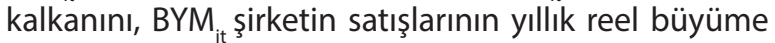
oranını ve $\varepsilon_{i t}$ modeldeki hata terimini ifade etmektedir.

Çimento, otomotiv ve bilişim sektörlerinde yer alan şirketlerin finansal tabloları kullanılarak hazırlanan sermaye yapısı ile ilgili değişkenlere ait tanımsal istatistikler Tablo 3'te yer almaktadır.

Tablo 3'ten de izlenebileceği gibi, çimento sektöründe ortalama borçluluk oranı (toplam borçların aktiflere oranı) yüzde 20 düzeyindedir. Sektördeki şirketlerin aktif kârlılıklarının ortalaması yüzde 10'dur ve varlık yapıları içinde maddi duran varlıkların oranı yüzde 47 'dir. Şirketlerin likidite durumlarını ortaya koyan asit-test oranının ortalaması sektörde 2007-2011 döneminde 2,78 olarak gerçekleşmiştir. Çimento sektörü incelenen dönemde satışlarında yaklaşık ortala- ma yüzde 2 düzeyinde bir düşüş yaşamıştır. Otomotiv sektöründe ortalama borçluluk oranı (toplam borçların aktiflere oranı) yüzde 45 düzeyindedir. Sektördeki şirketlerin aktif kârlııklarının ortalaması yüzde 8'dir ve varlık yapıları içinde maddi duran varlıkların oranı yüzde 32'dir. Şirketlerin likidite durumlarını ortaya koyan asit-test oranının ortalaması sektörde 2007-2011 döneminde 2,02 olarak gerçekleşmiştir. Otomotiv sektöründe incelenen dönemde satışlarda yaklaşık ortalama yüzde 6 düzeyinde bir artış yaşamıştır. Tablo 3'ten de görülebileceği gibi, bilişim sektöründe ortalama borçluluk oranı (toplam borçların aktiflere oranı) yüzde 49 düzeyindedir. Sektördeki şirketlerin aktif kârlılıklarının ortalaması yüzde 4'tür ve varlık yapıları içinde maddi duran varlıkların oranı yüzde 15'tir. Şirketlerin likidite durumlarını ortaya koyan asit-test oranının ortalaması sektörde 2007-2011 döneminde 2,28 olarak gerçekleşmiştir. Bilişim sektöründe incelenen dönemde satışlarda yaklaşık ortalama yüzde 22 düzeyinde bir artış yaşamıştır.

Incelenen sektörlerde faaliyet gösteren şirketlerin değişkenlerinin tanımsal istatistikleri karşılaştırıldığında, her bir sektörün kendine has özelliklerinin oranlara yansıdığı görülmektedir. En düşük borçlanma düzeyi çimento sektörüne aitken, en yüksek borçlanma hızlı büyüyen bilişim sektöründedir. Üç sektörde de uzun vadeli borç düşük bir oranda kalmış, yüzde 10'lara dahi çıkamamıştır. En yüksek aktif kârlıığı çimento sektöründeki şirketlere aittir. Bu sektör hem yüksek kâr marjı ile çalışmakta hem de bu sektörün aktiflerinin devri 


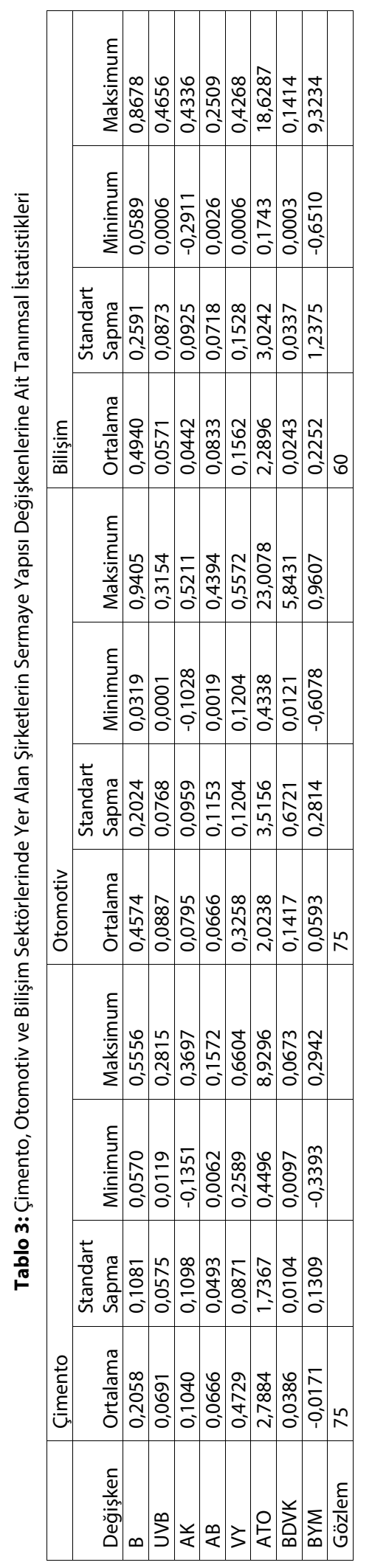

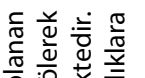

oldukça hızlıdır. Bu nedenle de yüzde 10 düzeyinde bir aktif kârlılığına sahiptir. Varlıkları içinde çimento sektörünün maddi duran varlıkları en yüksek seviyededir. Bilişim sektörü ise daha ziyade maddi olmayan duran varlıklara sahip olduğundan varlık yapısı oranı yüzde 15 düzeyinde kalmıştır. Her ne kadar çimento sektöründeki şirketler 2010-2011 döneminde satışlarını reel olarak arttırmış olsalar da, 2008 yılındaki küresel kriz bu şirketlerin satışlarını 2008 ve 2009 yıllarında ciddi oranlarda düşürmüştür. Bu da şirketlerin ortalamada yüzde 2 küçülmelerine neden olmuştur. Benzer şekilde otomotiv şirketleri de 2008 ve 2009 yıllarında satışlarında reel olarak düşüş yaşamış olmalarına rağmen, 2010 ve 2011 yıllarında çok yüksek oranda büyümeleri (bazı şirketler reel olarak yüzde 50 civarında satışlarını arttırmışlardır) ortalamada yaklaşık yüzde $6^{\prime}$ Iık bir büyüme yakalamalarına yardımcı olmuştur.

Modellerde kullanılan bağımsız değişkenler arasındaki korelasyon matrisi, her bir sektör için ayrı ayrı olmak üzere Ek 1'de verilmiştir. Korelasyon matrislerinden de görülebileceği gibi, özsermaye kârlıı̆ı ile aktif kârlııı̆ı dışında, incelenen her bir sektörde yer alan bağımsız değişkenler arasında anlamlı bir korelasyon katsayısına rastlanmamıştır. Bu nedenle de yukarıda "3.3.1.Değişkenlerin Belirlenmesi" bölümünde bahsi geçen tüm bağımsız değişkenler modellere dahil edilmiştir.

\subsection{Durağanlık Testleri}

Bütün zaman serileri analizlerinde olduğu gibi, hem zaman hem de yatay kesit analizini bir arada gerçekleştiren panel veri analizlerinde de değişkenler arasında sahte ilişkilere neden olunmaması için değişkenlerin durağan olması gerekmektedir. Çalışmada panel birim kök testlerinden Levin, Lin ve Chu testi ile ortak birim kök süreçleri araştırılırken, bunun yanı sıra her birim için PP-Fisher testi ile birim kök süreci test edilmiştir. Birimlerden bağımsız serilerde durağanlık ise Genelleştirilmiş Dickey Fuller (ADF) birim kök sınama yöntemi ile incelenmiş̧ir. Levin, Lin ve Chu testinde ortak birim kökün varlığına dair boş hipotez test edilmekte iken, PP-Fisher testinde bireysel birim kökün varlığına dair boş hipotez test edilmektedir. Panel birim-kök testi için Eviews paket programı kullanılmıştır. Durağanlık testleri bulgularına göre, çimento sektörüne ait değişkenlerden UVB, AK ve BYM seviyede durağan bulunurken; diğer değişkenlerin birinci farkları alındığında durağan oldukları tespit edilmiştir. Otomotiv sektöründe ise $A B, B Y M, V Y$ ve $B D V K$ seviyede durağan çıkmış, diğer değişkenler birinci farkları alındığında durağan bulunmuşlardır. Bilişim sektörüne ait değişkenlerden yalnız BYM seviyede durağan, diğerleri birinci farkta durağan bulunmuşlardır. 


\subsection{Panel Veri Analizi Model Seçim Kriterleri}

Panel veri analizinde Hausman Testi, Sabit Etkiler (Fixed Effects) ve Rassal Etkiler (Random Effects) yöntemleri arasında bir seçim yapılması gerektiği zaman, hangi modelin tercih edilmesi gerektiğine karar verilmesinde kullanılan bir testtir (Green, 2003: 379). Bu çalışmada panel veri analizinde, sabit etkiler ve rassal etkiler yöntemlerinden hangisinin kullanılacağına ka- rar vermek için Hausman testi yapılmış ve her iki model parametreleri arasındaki farkın istatistiksel olarak anlamlı olup olmadığı incelenmiştir. Her bir model için elde edilen Hausman test istatistikleri aşağıda Tablo 4'te yer almaktadır. Yalnızca çimento sektörünün toplam borçluluğunu açıklamak için kurulan modelde rassal kesit için sabit modelin kurulması gerektiği ortaya çıkmıştır. Diğer modellerde sabit etkiler yönteminin kullanılmasına dair bulgular elde edilmiştir.

Tablo 4: Her Bir Model için Hausman Test İstatistiği Sonuçları

\begin{tabular}{|l|c|c|c|c|}
\hline \multicolumn{1}{|c|}{ Test Özeti } & $\begin{array}{c}\text { Ki-Kare } \\
\text { İstatistiği }\end{array}$ & $\begin{array}{c}\text { Ki-Kare } \\
\text { d.f. }\end{array}$ & $\begin{array}{c}\text { Olasılık } \\
\text { Değeri }\end{array}$ & Model \\
\hline Çimento (B) Modeli için Rassal Kesit & 15.9779 & 6 & 0.0139 & Sabit \\
\hline Çimento (UVB) Modeli için Rassal Kesit & 6.4707 & 6 & 0.3726 & Rassal \\
\hline Otomotiv (B) Modeli için Rassal Kesit & 5.0220 & 6 & 0.5410 & Rassal \\
\hline Otomotiv (UVB) Modeli için Rassal Kesit & 0.9858 & 6 & 0.9861 & Rassal \\
\hline Bilişim (B) Modeli için Rassal Kesit & 10.0433 & 6 & 0.1228 & Rassal \\
\hline Bilişim (UVB) Modeli için Rassal Kesit & 3.1557 & 6 & 0.7891 & Rassal \\
\hline
\end{tabular}

\section{ARAŞTIRMANIN BULGULARI}

Araştırmanın bulgularını anlatmadan önce, regresyon analizinin iki önemli varsayımından bahsetmek yerinde olacaktır. Bu varsayımlardan ilki otokorelasyondur. Bütün zaman serilerinde olduğu gibi panel veri analizlerinde de otokorelasyon önemli bir sorundur. Bilindiği üzere, regresyon analizlerinin temel varsayımlarından birisi farklı gözlemler için aynı hatalar arasında ilişkinin olmamasıdır. Çalışmamızda hiçbir modelde otokorelasyon sorununa rastlanmamıştır. Otokorelasyon testlerinin bulgularının yer aldığı tablolar Ek 2'de verilmiştir. Regresyon analizinin

Tablo 5: Çimento Sektöründe Yer Alan Şirketlerin Uzun Vadeli ve Toplam Borçluluk Oranlarını Belirleyen Faktörler için Yapılan Panel Veri Analizi Bulguları

\begin{tabular}{|c|c|c|c|c|c|c|}
\hline \multirow{3}{*}{ Değişken } & \multicolumn{6}{|c|}{ Çimento Sektörü } \\
\hline & \multicolumn{2}{|c|}{ EKK } & \multicolumn{2}{|c|}{ Sabit Etkiler } & \multicolumn{2}{|c|}{ Rassal Etkiler } \\
\hline & UVB & B & UVB & B & UVB & B \\
\hline \multirow{3}{*}{ AK } & $-0,1212$ & $-0,1613^{* *}$ & $-0,0264$ & $-0,5952^{* * *}$ & $-0,0727$ & $-0,1318$ \\
\hline & $(0,0827)$ & $(-0,0742)$ & $(0,1398)$ & $(0,1694)$ & $(0,1024)$ & $(0,0727)$ \\
\hline & {$[0,1491]$} & {$[0,0341]$} & {$[0,8511]$} & {$[0,0012]$} & {$[0,4812]$} & {$[0,0761]$} \\
\hline \multirow{3}{*}{$A B$} & 2,4053 & $4,7995^{* * *}$ & $3,3176^{* * *}$ & $4,7902^{* * *}$ & 3,0774 & $4,9549 * * *$ \\
\hline & $(1,4451)$ & $(1,2956)$ & $(1,2020)$ & $(1,4557)$ & $(1,1724)$ & $(1,3108)$ \\
\hline & {$[0,1019]$} & {$[0,0005]$} & {$[0,0090]$} & {$[0,0022]$} & {$[0,0115]$} & {$[0,0004]$} \\
\hline \multirow{3}{*}{ VY } & 0,2264 & 0,2744 & $0,3935^{* *}$ & 0,2815 & 0,3478 & 0,2503 \\
\hline & $(0,1843)$ & $(0,1652)$ & $(0,1683)$ & $(0,2038)$ & $(0,1622)$ & $(0,1732)$ \\
\hline & {$[0,2246]$} & {$[0,1026]$} & {$[0,0250]$} & {$[0,1758]$} & {$[0,0370]$} & {$[0,1548]$} \\
\hline \multirow{3}{*}{ ATO } & 0,0053 & $-0,0142^{* *}$ & 0,0008 & $-0,0078$ & 0,0023 & $-0,0099$ \\
\hline & $(0,0062)$ & $(0,0056$ & $(0,0049)$ & $(0,0060)$ & $(0,0048)$ & $(0,0055)$ \\
\hline & {$[0,3971]$} & {$[0,0142]$} & {$[0,8644]$} & {$[0,2015]$} & {$[0,6314]$} & {$[0,0803]$} \\
\hline \multirow{3}{*}{ BDVK } & 0,5381 & 0,2290 & 0,8497 & 0,9054 & 0,7641 & 0,5326 \\
\hline & $(1,2124)$ & $(1,0869)$ & $(0,9878)$ & $(1,1963)$ & $(0,9596)$ & $(1,0698)$ \\
\hline & {$[0,6590]$} & {$[0,8339]$} & {$[0,3954]$} & {$[0,4541]$} & {$[0,4296]$} & {$[0,6207]$} \\
\hline \multirow{3}{*}{ BYM } & 0,0932 & 0,0747 & $-0,0181$ & 0,0394 & 0,0004 & $-0,0150$ \\
\hline & $(0,0644)$ & $(0,0578)$ & $(0,0612)$ & $(0,0742)$ & $(0,0588)$ & $(0,0674)$ \\
\hline & {$[0,1538]$} & {$[0,2015]$} & {$[0,7690]$} & {$[0,5986]$} & {$[0,9944]$} & {$[0,8250]$} \\
\hline \multirow{3}{*}{ Sabit } & 0,0830 & 0,0262 & 0,0722 & 0,0600 & 0,0764 & 0,0220 \\
\hline & $(0,0107)$ & $(0,0096)$ & $(0,0130)$ & $(0,0158)$ & $(0,0103)$ & $(0,0092)$ \\
\hline & {$[0,0000]$} & {$[0,0086]$} & {$[0,0000]$} & {$[0,0005]$} & {$[0,0000]$} & {$[0,0216]$} \\
\hline $\mathrm{R}^{2}$ & 0,0992 & 0,3496 & 0,7060 & 0,6128 & 0,1815 & 0,4244 \\
\hline $\begin{array}{c}\text { Düzeltilmiş } \\
\mathrm{R}^{2}\end{array}$ & $-0,0027$ & 0,2760 & 0,5182 & 0,3654 & 0,0342 & 0,3208 \\
\hline F-istatistiği & 0,9731 & $4,7496^{* * *}$ & $3,7594^{* * *}$ & $2,4770^{* * *}$ & 1,2326 & $4,0974^{* * *}$ \\
\hline $\begin{array}{c}\text { Gözlem } \\
\text { Sayısı }\end{array}$ & 60 & 60 & 60 & 60 & 60 & 60 \\
\hline
\end{tabular}

(Not: Standart hatalar katsayıların hemen altında parantez içinde yer almaktadır. p-değerleri ise köşeli ayraçlar içinde verilmiştir. ${ }^{* * *} \% 99$ ve ** $\% 95$ güven aralığında istatistiksel açıdan anlamlılığı ifade etmektedir) 
ikinci önemli varsayımı eşvaryanslılıktır (heteroscedasticity). Panel veri analizinde modelin farklı varyans sorununun tespiti için "Değişen Varyans Testi" yapılmıştır. Bu çalışmada hiçbir modelde farklı varyans sorununa rastlanmamıştır. Eşvaryanslılık testlerinin bulgularının yer aldığı tablolar Ek 3'te verilmiştir.

Üç farklı sektörde sermaye yapısı kararlarını etkileyen faktörlerin incelendiği bu çalışmada, panel veri analizi kapsamında En Küçük Kareler (EKK) (Ordinary Least Square-OLS) tahmini ile analizler gerçekleştirilmiştir. Ayrıca veri setimiz şirketleri ve farklı zaman dilimlerini kapsadığı için Sabit Etkiler ve Rassal Etkiler yöntemleri ile de analizler yapılmıştır. Araştırmanın bulguları aşağıda Tablo 5, Tablo 6 ve Tablo 7'de her bir sektör için ayrı olmak üzere yer almaktadır. Hausman test istatistiğine göre seçilen yöntemlerin bulguları kalın harflerle verilmiştir:

2007-2011 döneminde çimento sektörü şirketlerinin uzun vadeli borçlarının toplam aktiflerine oranını etkileyen faktörlerin araştıııldığı ilk modelde, gerek EKK modelinin gerekse de rassal etkiler yönteminin F-istatistiği bu değişken için bir model oluşturulamadığını göstermektedir. Sabit etkiler yönteminde F-istatistiği ise kurulan modelin anlamlı olduğunu söylemektedir. Modelin açıklayıcılık gücü \% 70'tir ve model çimento şirketlerinin uzun vadeli borç düzeyinde büyüklüğün ve varlık yapısının etkili olduğunu söylemektedir. Ancak Hausman test istatistik sonuçlarına göre (Tablo 4) bu modelde rassal etkiler yöntemini kullanmak gerektiği ortaya çıktığından, çimento şirketlerinin uzun vadeli borçları için herhangi bir açıklayıcı model oluşturulamadığını söylemek yerinde olacaktır.

Çimento sektörü şirketlerinin 2007-2011 döneminde toplam borçlarının toplam aktiflerine oranını etkileyen faktörlerin araştııılığı model sonuçları yine Tablo 5 'ten izlenebilir. F-istatistiklerine bakıldığında kullanılan tüm yöntemlere göre modeller anlamlı çıkmıştır. Aktif kârlılığı, büyüklük ve likidite borçluluk oranlarını etkileyen faktörler olarak bulunmuştur. Hausman test istatistik sonuçlarına göre (Tablo 4) bu modelde sabit etkiler yöntemini kullanmak gerektiği bulunmuştur. Bunun yanında, sabit etkiler modeli tüm yöntemler içinde kurulan modelin açıklayıcılık gücü bakımından en yüksek değere sahiptir (\%61). Bu nedenle bu yöntemin bulgularını anlatmak daha doğru olacaktır. Kurulan modelde aktif büyüklügünün $(A B)$ ve aktif kârlıığının katsayıları anlamlı çıkmıştır. Incelenen dönemde borçluluğu etkileyen $A B^{\prime}$ nin katsayısı pozitiftir $(4,7902)$. Bir başka deyişle, şirket büyüklügündeki artışlar borçluluğu arttırmaktadır. Çimento sektöründe aktif kârlıı̆̆ı ile borçluluk arasında ise anlamlı negatif bir ilişki bulunmuştur $(-0,5952)$. Elde edilen bulgular çimento sektöründe hem dengeleme kuramının (büyüklük ile borçluluk arasında pozitifi ilişki çıkması), hem de finansman hiyerarşisi kuramının (kârlılık ile borçluluk arasında negatif ilişki çıkması) izlerini taşımaktadır. Finansman hiyerarşisi kuramı Türkiye'de sermaye yapısını araştıran çalışmaların birçoğunda elde edilen sonuçtur (Durukan, 1997b; Acaravcl, 2004; Fıratoğlu, 2005; Korkmaz, Başaran ve Gökbulut, 2009; Teker, Taşseven ve Tükel, 2009; Terim ve Kayalı, 2009; Yükeri, 2009, Okuyan ve Taşçı, 2010 ve Güler, 2010). Dengeleme kuramını destekleyen bir çalışma Clark, Francis ve Hasan (2009) tarafından yapılmış ve hem gelişmiş hem de gelişmekte olan ülkelerde kuramın geçerli olduğunu 40 ülke için ortaya koymuştur. Ayrıca Booth vd.(2001), Pandey (2001) ve Prasad vd. (2003) de dengeleme kuramını destekleyen bulgulara ulaşmışlardır. Bu çalışmanın kapsadığı yıllar olan 2008-2009 döneminde Türkiye'de küresel finansal krizin etkileri hissedilmiştir. Bu çalışmanın bulgularının kriz öncesi dönemi inceleyen çalışmalardan farklı çıkmasının nedenlerinden birisi olarak, şirketlerin sermaye yapılarında krizin etkilerinin hissedilmiş olması düşünülebilir. Deesomsak, Paudyal ve Pescetto (2004), Asya-Pasifik bölgesinde incelediği dört ülkenin sermaye yapıları belirleyicilerinin kriz öncesi ve sonrasında farklılaştığını ortaya koymuştur. Çalışmada, kriz sonrası dönemde kredi verirken risklerinin daha düşük olması nedeniyle büyük şirketlerin bankalar tarafından daha çok tercih edildiği vurgulanmıştır. Bu nedenle de büyüklük ile borçluluk arasında pozitif bir ilişki bulunmuştur. Aynı durumun, Türkiye Ekonomisi için de geçerli olabileceği düşünülmektedir.

Otomotiv sektörünün sermaye yapısı ile ilgili bulgular Tablo 6'dan izlenebilir. 2007-2011 döneminde otomotiv şirketlerinin uzun vadeli borçlarının toplam aktiflerine oranını etkileyen faktörlerin araştııldığı modelde, kullanılan üç yönteme göre de modelin F-istatistiği bu değişken için bir model oluşturulamadığını göstermektedir. Otomotiv şirketlerinin uzun vadeli borçluluk düzeyleri, incelenen dönem için modellenememiştir. Otomotiv şirketlerinin toplam borçlarının toplam aktiflerine oranını etkileyen faktörlerin araştırıldığı modelde, tüm yöntemlerde, Tablo 6'dan da görülebileceği gibi, satışların büyümesi değişkeni dışında tüm değişkenlerin katsayıları anlamsız çıkmıştır. İncelenen dönemde toplam borçların toplam aktiflere oranını etkileyen BYM'nin katsayısı pozitiftir $(0,0891)$. Bir başka deyişle, satışlardaki artışlar toplam borçluluğu arttırmakta ve sermaye yapısını değiştirmektedir. Satış hacimleri büyüyen şirketler bu büyümeyi finanse edebilmek için borç kullanma eğilimindedirler. Bu bulgu, büyüme ile borçluluk yapısı arasında olması beklenen pozitif ilişkiyi desteklemektedir. Modelin R-Kare değeri \%35 olarak oldukça yüksek bir değer bulunmuştur ve otomotiv sektöründe borçluluk düzeyindeki değişmelerin yaklaşık olarak yüzde 35'inin satış büyümesi tarafından açıklandığını göstermektedir. 
Tablo 6: Otomotiv Sektöründe Yer Alan Şirketlerin Uzun Vadeli ve Toplam Borçluluk Oranlarını Belirleyen Faktörler için Yapılan Panel Veri Analizi Bulguları

\begin{tabular}{|c|c|c|c|c|c|c|}
\hline \multirow{3}{*}{ Değişken } & \multicolumn{6}{|c|}{ Otomotiv Sektörü } \\
\hline & \multicolumn{2}{|c|}{ EKK } & \multicolumn{2}{|c|}{ Sabit Etkiler } & \multicolumn{2}{|c|}{ Rassal Etkiler } \\
\hline & UVB & B & UVB & $\mathrm{B}$ & UVB & B \\
\hline \multirow{3}{*}{ AK } & $-0,1438$ & $-0,2687$ & $-0,0812$ & $-0,2816$ & $-0,0963$ & $-0,2678$ \\
\hline & $(0,1194)$ & $(0,1403)$ & $(0,1513)$ & $(0,1433)$ & $(0,1456)$ & $(0,1393)$ \\
\hline & {$[0,2338]$} & {$[0,0609]$} & {$[0,5946]$} & {$[0,0572]$} & {$[0,5112]$} & {$[0,0602]$} \\
\hline \multirow{3}{*}{$A B$} & 0,0110 & 0,0121 & 0,9451 & $-2,9863$ & 0,0199 & 0,0394 \\
\hline & $(0,0909)$ & $(0,1068)$ & $(2,0237)$ & $(1,9168)$ & $(0,1047)$ & $(0,1138)$ \\
\hline & {$[0,9034]$} & {$[0,9102]$} & {$[0,6433]$} & {$[0,1280]$} & {$[0,8495]$} & {$[0,7304]$} \\
\hline \multirow{3}{*}{ VY } & 0,0459 & 0,0586 & 0,0186 & $-0,0326$ & 0,0237 & 0,0244 \\
\hline & $(0,0617)$ & $(0,0725)$ & $(0,1971)$ & $(0,1867)$ & $(0,0742)$ & $(0,0803)$ \\
\hline & {$[0,4603]$} & {$[0,4221]$} & {$[0,9252]$} & {$[0,8621]$} & {$[0,7505]$} & {$[0,7626]$} \\
\hline \multirow{3}{*}{ ATO } & 0,0040 & 0,0008 & 0,0028 & $-0,0010$ & 0,0030 & $-0,0009$ \\
\hline & $(0,0034)$ & $(0,0040)$ & $(0,0044)$ & $(0,0042)$ & $(0,0042)$ & $(0,0040)$ \\
\hline & {$[0,2452]$} & {$[0,8281]$} & {$[0,5241]$} & {$[0,8107]$} & {$[0,4699]$} & {$[0,8102]$} \\
\hline \multirow{3}{*}{ BDVK } & 0,0003 & $-0,0272$ & 0,4088 & $-1,0875$ & $-0,0176$ & $-0,0752$ \\
\hline & $(0,1166)$ & $(0,1370)$ & $(0,6226)$ & $(0,5897)$ & $(0,1350)$ & $(0,1453)$ \\
\hline & {$[0,9977]$} & {$[0,8432]$} & {$[0,5156]$} & {$[0,0734]$} & {$[0,8964]$} & {$[0,6067]$} \\
\hline \multirow{3}{*}{ BYM } & 0,0425 & $0,1151^{* * *}$ & 0,0406 & $0,1098^{* *}$ & 0,0596 & $0,0891^{* *}$ \\
\hline & $(0,0315)$ & $(0,0370)$ & $(0,0483)$ & $(0,0458)$ & $(0,0423)$ & $(0,0414)$ \\
\hline & {$[0,1839]$} & {$[0,0031]$} & {$[0,4060]$} & {$[0,0218]$} & {$[0,1655]$} & {$[0,0363]$} \\
\hline \multirow{3}{*}{ Sabit } & $-0,0107$ & 0,0038 & $-0,0924$ & 0,3061 & $-0,0041$ & 0,0180 \\
\hline & $(0,0218)$ & $(0,0257)$ & $(0,1876)$ & $(0,1776)$ & $(0,0261)$ & $(0,0278)$ \\
\hline & {$[0,6252]$} & {$[0,8812]$} & {$[0,6251]$} & {$[0,0934]$} & {$[0,8735]$} & {$[0,5204]$} \\
\hline$R^{2}$ & 0,0408 & 0,2241 & 0,1437 & 0,5499 & 0,0689 & 0,3526 \\
\hline Düzeltilmiş $\mathrm{R}^{2}$ & $-0,0677$ & 0,1363 & $-0,4033$ & 0,2624 & $-0,0986$ & 0,2361 \\
\hline F-istatistiği & 0,3760 & $2,2552^{* *}$ & 0,2626 & $1,9129^{* *}$ & 0,4111 & $3,0269 * * *$ \\
\hline Gözlem Sayısı & 60 & 60 & 60 & 60 & 60 & 60 \\
\hline
\end{tabular}

(Not: Standart hatalar katsayıların hemen altında parantez içinde yer almaktadır. p-değerleri ise köşeli ayraçlar içinde verilmiştir. ${ }^{* * *} \% 99$ ve ** \% 95 güven aralığında istatistiksel açıdan anlamlılı̆̆ı ifade etmektedir)

Korkmaz, Başaran ve Gökbulut (2009) çalışmalarında büyüme ile borçluluk arasında teorinin ve bu çalışmanın bulgularının tersine negatif bir ilişki bulmuşlar ve bunu otomotiv sektöründe var olan hızlı büyüme sayesinde satışları ve aktifleri de hızla büyüyen şirketlerin, borçlanma yerine iç kaynaklarını kullandıklarını söyleyerek açıklamışlardır. Çalışmalarının bulguları arasında yer alan kârlılık ile borçluluk arasında çıkan negatif ilişki de bu tespitlerini kanıtlamaktadır. Bu çalışmada da benzer şekilde, hızlı büyüyen otomotiv şirketlerinin iç kaynaklarının yeterli olmadığı ve borçla finansmana yöneldikleri tespiti, kârlılık ile borçluluk arasında herhangi bir ilişki çıkmamasıyla kanıtlanmaktadır. Bu bulgulardan hareketle denilebilir ki, otomotiv sektörünün sermaye yapısı kararlarında 2007-2011 döneminde geçmiş dönemlerden farklı bir yapı oluşmuştur. Bunda sektörün hızlı büyümesinin ve kendi iç kaynaklarının yeterli gelmemesinin yanında, Türkiye Ekonomisi'nde borçlanmanın son dönemlerde cazip hale gelmesinin (düşen faiz oranları) etkili olduğu düşünülmektedir.

Tablo 7'de bilişim sektöründe yer alan şirketlerin borçluluk oranlarının belirlenmesine yönelik kurulan modelin bulguları yer almaktadır. Uzun vadeli borçluluğun belirleyicilerini bulabilmek için kurulan model- de, tüm yöntemlere göre, büyüklüğün $(A B)$ ve varlık yapısının (VY) katsayıları anlamlı çıkmıştır. İncelenen dönemde uzun vadeli borçluluğu etkileyen $A B^{\prime} n ı n$ katsayısı pozitiftir. Bir başka deyişle, AB'deki artışlar uzun vadeli borçluluğu arttırmaktadır. Elde edilen bu bulgu ile, 2007-2011 döneminde bilişim sektöründeki şirketlerin sermaye yapıları için dengeleme kuramının geçerli olduğunu söylemek mümkündür. Bu bulgunun nedeni, çimento sektörü için düşünülen nedenlerle aynıdır. Modeldeki diğer anlamlı değişken olan VY'nin katsayısı da pozitif çıkmıştır. Diğer bir deyişle, şirketin maddi duran varlıklarındaki artışlar uzun vadeli borçluluğu arttırmakta ve sermaye yapısını değiştirmektedir. Bu bulgu, varlık yapısı ile borçluluk yapısı arasında olması beklenen pozitif ilişkiyi destekler niteliktedir. Hausman test istatistik sonucuna göre kullanılması gereken yöntem olan rassal etkiler yöntemine göre, modelin R-kare değeri \%50 olarak bulunmuştur ve bilişim sektöründe uzun vadeli borçluluk düzeyindeki değişmelerin yaklaşık olarak yüzde 50'sinin şirket büyüklüğü ve varlık yapısı tarafından açıklandığını göstermektedir. Bilişim sektöründe yer alan şirketlerin toplam borçluluk oranlarının belirlenmesine yönelik kurulan modelde, tüm yöntemlere göre, büyüklüğün $(A B)$ ve büyümenin (BYM) katsayı- 
Tablo 7: Bilişim Sektöründe Yer Alan Şirketlerin Uzun Vadeli ve Toplam Borçluluk Oranlarını Belirleyen Faktörler için Yapılan Panel Veri Analizi Bulguları

\begin{tabular}{|c|c|c|c|c|c|c|}
\hline \multirow{3}{*}{ Değişken } & \multicolumn{6}{|c|}{ Bilişim Sektörü } \\
\hline & \multicolumn{2}{|c|}{ EKK } & \multicolumn{2}{|c|}{ Sabit Etkiler } & \multicolumn{2}{|c|}{ Rassal Etkiler } \\
\hline & UVB & B & UVB & B & UVB & B \\
\hline \multirow{3}{*}{ AK } & 0,0619 & $-0,1588$ & 0,1144 & $-0,1158$ & 0,0919 & $-0,1262$ \\
\hline & $(0,1015)$ & $(0,1504)$ & $(0,0941)$ & $(0,1646)$ & $(0,0908)$ & $(0,1482)$ \\
\hline & {$[0,5452]$} & {$[0,2974]$} & {$[0,2349]$} & {$[0,4877]$} & {$[0,3179]$} & {$[0,3996]$} \\
\hline \multirow{3}{*}{$A B$} & $0,9681^{* *}$ & $2,9712^{* * *}$ & $0,8992^{* * *}$ & $2,7547^{* * *}$ & $0,9200^{* * *}$ & $3,0462^{* * *}$ \\
\hline & $(0,3715)$ & $(0,5506)$ & $(0,3228)$ & $(0,5645)$ & $(0,3180)$ & $(0,5386)$ \\
\hline & {$[0,0127]$} & {$[0,0000]$} & {$[0,0097]$} & {$[0,0000]$} & {$[0,0063]$} & {$[0,0000]$} \\
\hline \multirow{3}{*}{ VY } & $0,3189^{* * *}$ & 0,0466 & $0,2965^{* * *}$ & 0,0559 & $0,2951^{* * *}$ & 0,0240 \\
\hline & $(0,0860)$ & $(0,1275)$ & $(0,0742)$ & $(0,1298)$ & $(0,0737)$ & $(0,1271)$ \\
\hline & {$[0,0006]$} & {$[0,7165]$} & {$[0,0005]$} & {$[0,6698]$} & {$[0,0003]$} & {$[0,8512]$} \\
\hline \multirow{3}{*}{ ATO } & 0,0030 & $-0,0015$ & $-0,0001$ & $-0,0034$ & 0,0003 & $-0,0025$ \\
\hline & $(0,0040)$ & $(0,0059)$ & $(0,0036)$ & $(0,0063)$ & $(0,0035)$ & $(0,0059)$ \\
\hline & {$[0,4464]$} & {$[0,7927]$} & {$[0,9630]$} & {$[0,5884]$} & {$[0,9157]$} & {$[0,6708]$} \\
\hline \multirow{3}{*}{ BDVK } & $-0,4776$ & $-0,6836$ & $-0,6474$ & $-0,9570$ & $-0,6055$ & $-0,7566$ \\
\hline & $(0,4725)$ & $(0,7003)$ & $(0,4096)$ & $(0,7161)$ & $(0,4073)$ & $(0,7037)$ \\
\hline & {$[0,3180]$} & {$[0,3347]$} & {$[0,1256]$} & {$[0,1926]$} & {$[0,1454]$} & {$[0,2891]$} \\
\hline \multirow{3}{*}{ BYM } & 0,0016 & $0,0430^{* * *}$ & 0,0012 & $0,0520^{* * *}$ & 0,0011 & $0,0386^{* * *}$ \\
\hline & $(0,0060)$ & $(0,0090)$ & $(0,0062)$ & $(0,0108)$ & $(0,0058)$ & $(0,0093)$ \\
\hline & {$[0,7928]$} & {$[0,0000]$} & {$[0,8370]$} & {$[0,0001]$} & {$[0,8497]$} & {$[0,0002]$} \\
\hline \multirow{3}{*}{ Sabit } & 0,0182 & 0,0114 & 0,0177 & 0,0092 & 0,0179 & 0,0119 \\
\hline & $(0,0076)$ & $(0,0113)$ & $(0,0063)$ & $(0,0110)$ & $(0,0063)$ & $(0,0110)$ \\
\hline & {$[0,3180]$} & {$[0,3178]$} & {$[0,0093]$} & {$[0,4101]$} & {$[0,0072]$} & {$[0,2842]$} \\
\hline & & & & & & \\
\hline $\mathrm{R}^{2}$ & 0,3360 & 0,6787 & 0,7032 & 0,8001 & 0,5043 & 0,6945 \\
\hline Düzeltilmiş $\mathrm{R}^{2}$ & 0,2388 & 0,6317 & 0,4833 & 0,6521 & 0,3870 & 0,6222 \\
\hline F-istatistiği & $3,4579 * * *$ & $14,4399 * * *$ & $3,1987^{* * *}$ & $5,4049 * * *$ & $4,2970 * * *$ & $9,6015^{* * *}$ \\
\hline Gözlem Sayısı & 48 & 48 & 48 & 48 & 48 & 48 \\
\hline
\end{tabular}

(Not: Standart hatalar katsayıların hemen altında parantez içinde yer almaktadır. p-değerleri ise köşeli ayraçlar içinde verilmiştir. *** \% 99 ve ** \% 95 güven aralığında istatistiksel açıdan anlamlılığı ifade etmektedir)

ları anlamlı çıkmıştır. İncelenen dönemde borçluluğu etkileyen AB'nin katsayısı pozitiftir. Bir başka deyişle, $A B^{\prime}$ deki artışlar toplam borçluluğu arttırmaktadır. Elde edilen bu bulgu ile, 2007-2011 döneminde bilişim sektöründeki şirketlerin sermaye yapıları için dengeleme kuramının geçerli olduğunu söylemek mümkündür. Modeldeki diğer anlamlı değişken olan BYM'nin katsayısı da pozitif çıkmıştır. Diğer bir deyişle, şirketin satışlarındaki artışlar borçluluğu arttırmaktadır. Bu bulgu, büyüme ile borçluluk yapısı arasında olması beklenen pozitif ilişkiyi desteklemektedir. Hausman test istatistik sonucuna göre kullanılması gereken yöntem olan rassal etkiler yöntemine göre, modelin R-Kare değeri 0,6945 olarak oldukça yüksek bir değer bulunmuştur ve bilişim sektöründe borçluluk düzeyindeki değişmelerin yaklaşık olarak yüzde 69'unun şirket büyüklüğü ve satışların büyümesi tarafından açıklandığını göstermektedir.

\section{SONUÇ}

Bu çalışmada çimento, otomotiv ve bilişim sektörlerinde faaliyet gösteren şirketlerin sermaye yapılarının belirleyicileri tespit edilmeye çalışılmıştır.
Çalışmanın amacı, sektörler arasında sermaye yapısı belirleyicilerinin farklılık arz edip etmediğinin ortaya konmasıdır.

Analizlerden elde edilen bulgulara göre, sermaye yapısını belirleyen faktörler sektörden sektöre farklılık arz etmektedir. Çimento sektöründe aktif büyüklüğü ve kârlılık borçluluk oranı üzerinde etkili olurken; otomotivde satışların büyüme hızı, bilişim sektöründeyse büyüklük, varlık yapısı ve satışların büyüme hızı borç değişkenini etkilemektedir. Çimento sektöründe şirketin büyüklüğü arttıkça borçluluk oranları da yükselmektedir. Bu bulgu, büyük şirketlerin daha düşük risk içermelerinden dolayı daha yüksek oranlarda borçlanabileceklerini belirten dengeleme kuramını destekler niteliktedir. Bir başka nokta, bu çaıışmanın kapsadığı yıllar olan 2008-2009 döneminde Türkiye'de küresel finansal krizin etkilerinin hissedilmiş olmasıdır. Bu çalışmanın bulgularının kriz öncesi dönemi inceleyen çalışmalardan farklı çıkmasının nedenlerinden birisi olarak, şirketlerin sermaye yapılarında krizin etkilerinin hissedilmiş olması düşünülebilir. Kriz sonrası dönemde kredi verirken risklerinin daha düşük olması nedeniyle büyük şirketlerin ban- 
kalar tarafından daha çok tercih edildiği düşünülmektedir. Bu nedenle de büyüklük ile borçluluk arasında pozitif bir ilişki bulunmuştur.

Otomotiv sektörü için kurulan borçluluk modellerine göre, satışları artan şirketler daha çok borç kullanma eğiliminde olmaktadırlar. Büyüme ile borçluluk arasında olması beklenen pozitif ilişki, Türkiye'deki otomotiv şirketleri için geçerlidir. Daha önce yapılan bir çalışmada (Korkmaz, Başaran ve Gökbulut, 2009) bu iki değişken arasında negatif bir ilişki bulunmaSı, otomotiv sektörünün sermaye yapısı kararlarında 2007-2011 döneminde geçmiş dönemlerden farklı bir yapı oluştuğunu göstermektedir. Bunda sektörün hızIı büyümesinin ve kendi iç kaynaklarının yeterli gelmemesinin yanında, Türkiye Ekonomisi'nde borçlanmanın son dönemlerde cazip hale gelmesinin (düşen faiz oranları) etkili olduğu düşünülmektedir.

Bilişim şirketleri büyüdükçe borçlulukları da artmaktadır. Bunda, Türkiye'de büyük şirketlerin kredi kaynaklarına ulaşmada küçük şirketlere göre daha avantajlı olmasının etkili olduğu düşünülmektedir. Daha kolay ve daha düşük faizle kredi bulabilen büyük şirketler, kendi kaynaklarını kullanmaktansa, kredi kullanmayı tercih etmektedirler. Bilişim sektörünün borçluluk yapısında etkili olan bir başka değişken satışların büyüme hızıdır. Büyüme oranları yüksek olan bilişim şirketlerinin iç fonları, finansal ihtiyaçlarını karşılamak için yeterli olmamaktadır. Bu nedenle de bu şirketler borçlanmalarını arttırmaktadır. Aktif yapısı içinde maddi olmayan duran varlıklarının oranı yüksek olan bilişim şirketleri, maddi duran varlıklarının artmasıyla daha fazla borç kullanır hale gelmektedir. Bunun nedeni, maddi duran varlıkların borç alırken teminat gösterilebilmesi, maddi duran varlıkları yüksek olan şirketlerin kredibilitelerinin yüksek olacağı ve daha yüksek oranlarda borç kullanabilecek olmalarıdır.

Çimento, otomotiv ve bilişim sektörlerini inceleyen bu çalışmanın ardından diğer alt sektörlerin sermaye yapılarını inceleyen çalışmalar yapmak, sektörler arası farklılıkları vurgulamak açısından oldukça önemlidir. Özellikle son yıllarda artan önemi nedeniyle enerji sektörünü incelemek, literatüre büyük bir katkı sağlayacaktır. Bunun dışında, krizin sermaye yapıları üzerindeki etkilerini incelemek, şirketlerin kriz dönemlerindeki finansal kararlarını öğrenmek ve önlemler almak açısından önem arz etmektedir. 20082009 küresel finans krizinin etkileri henüz veri sayısı yeterli olmadığından incelenememektedir. Fakat birkaç sene sonra, konuya bu noktadan bakan çalışmaların yapılmasının hem akademisyenler hem de uygulamacılar için oldukça yararlı olacağı düşünülmektedir. 


\section{KAYNAKLAR}

Acaravcı, S.K. (2004) "Gelişmekte Olan Ülkelerde Sermaye Yapısını Etkileyen Faktörler: Türkiye'de Bir Uygulama” Yayınlanmamış Doktora Tezi, Adana, Çukurova Üniversitesi Sosyal Bilimler Enstitüsü.

Akhtar, S. (2005) “The Determinants of Capital Structure for Australian Multinational and Domestic Corporations" Australian Journal of Management, 30(2): 321-341.

Anwar, W. (2012) "Cross-Industry Determinants of Capital Structure: Evidence from Pakistani Data" International Journal of Management and Innovation, 4(1):79-86.

Ata, H.A. ve Ağ, Y. (2010) "Firma Karakteristiğinin Sermaye Yapısı Üzerindeki Etkisinin Analizi” Ekonometri ve Istatistik, 11: 45-60

Bhaduri, S.N. (2002) "Determinants of Capital Structure Choice: A Study of the Indian Corporate Sector" Applied Financial Economics, 12:655-665.

Brigham, E.F. ve Houston, J.F. (1999) Fundamentals of Financial Management, Concise Second Edition, Orlando, The Dryden Press.

Booth, L., Aivazian, V., Demirgüç-Kunt, A. ve Maksimovic, V. (2001) "Capital Structures in developing Countries" The Journal of Finance, 61(1):87-129.

Cassar, G. ve Holmes, S. (2003) "Capital Structure and Financing of SMEs: Australian Evidence" Accounting and Finance, (43):123-147.

Chen, J. J. (2004) "Determinants of Capital Structure of Chinese-Listed Companies" Journal of Business Research, 57:1341-1351.

Clark, B., Francis, B. ve Hasan, I. (2009) "Do Firms Adjust Towards Target Capital Structures? Some International Evidence" Lally School of Management and Technology of Rensselaer Politechnik Institute in Troy Working Paper Series.

Colombo, E. (2001) "Determinants of Corporate Capital Structure: Evidence from Hungarian Firms" Applied Economics, (33):1689-1701.

Crnigoj, M. ve Mramor, D. (2009) “Determinants of Capital Structure in Emerging European Economies: Evidence from Slovenian Firms" Emerging Markets Finance and Trade, 45(1): 72-89.

De Angelo, H. ve Masulis, R.W. (1980) "Leverage and Dividend Irrelevancy Under Corporate and Personal Taxation" Journal of Finance, 35(2): 453-64.

De Mederios, O.R. ve Daher, C.E. (2005) “Testing Static Tradeoff Against Pecking Order Models of Capital Structure in Brazilian Firms" http://papers.ssrn.com/ sol3/papers.cfm?abstract_id=631563, (5.12.2012)
Deesomsak, R., Paudyal, K, ve Pescetto, G. (2004) "The Determinants of Capital Structure: Evidence from the Asia Pasific Region" Journal of Multinational Financial Management, (14):387-405.

Demirhan, D. (2009) "Sermaye Yapısını Etkileyen Firmaya Özgü Faktörlerin Analizi: İMKB Hizmet Firmaları Üzerine Bir Uygulama” Ege Akademik Bakıs, 9(2): 677-697.

Durukan, M.B. (1997b) "Hisse Senetleri İMKB'de İşlem Gören Firmaların Sermaye Yapısı Üzerine Bir Araştırma 1990-1995” İMKB Dergisi, 1(3):75-87.

Fama, E.F. (1980) "Agency Problems and the Theory of the Firms" The Journal of Political Economy, 88(2):288307.

Fama, E. ve French, K. (2002) "Testing Tradeoff and Pecking Order Predictions About Dividends and Debt" Review of Financial Studies, 15:1-33.

Fıratoğlu, B. (2005) "Şirketlerin Sermaye Yapısını Etkileyen Faktörler ve Kriz Dönemlerinde Şirket Davranışlarında Meydana Gelen Değişiklikler” SPK Araştırma Raporu.

Frank, M. ve Goyal, V. (2003) "Testing The Pecking Order Theory of Capital Structure" Journal of Financial Economics, 67:217-248.

Gitman, L.J. (2003) Principles of Managerial Finance, 10th Edition, Boston, Pearson Education Inc.

Green, S. (2003) “Two-Thirds Privatisation: How It Happens” Chatham House Briefing Note, Royal Institute of International Affairs, Londra.

Güler, S. (2010) "İstanbul Menkul Kiymetler Borsasına (İMKB) Kayıtlı Küçük ve Orta Büyüklükteki İşletmelerin (KOBİ) Sermaye Yapıları Üzerine Bir Uygulama” Süleyman Demirel Üniversitesi İktisadi ve İdari Bilimler Fakültesi Dergisi, 15(3):353-371.

Güloğlu, B. ve Bekçioğlu, S. (2002) “İMKB’deki Gelişmelerin Şirketlerin Sermaye Yapısına Etkileri: İmalat Sanayinde Faaliyet Gösteren Firmalar Üzerine Bir Uygulama” ODTÜ Uluslararası İktisat Kongresi, Ankara.

Harris, M. ve Raviv, A. (1991) "The Theory of Capital Structure" Journal of Finance, 49: 297-355.

Haugen, R.A. ve Senbet, L.W. (1978) “The Insignificance of Bankruptcy Costs to the Theory of Optimal Capital Structure" The Journal of Finance, 33(2):383-393.

Huang, G. ve Song, F.M. (2002) "The Determinants of Capital Structure: Evidence from China” China Economic Review, (17):14-36.

Ismail, M. ve Eldomiaty, T. (2005) "Bayesian Identification of the Predictors for Capital Structure in Egypt" Advances and Applications in Statistics, 5(1):1-20. 
Jensen, M. ve Meckling, W. (1976) "Theory of the Firm: Managerial Behaviour, Agency Costsand Capital Structure" Journal of Financial Economics, 3:11- 25.

Kraus, A. ve Litzenberger, R.H. (1973) "A State-Preference Model of Optimal Capital Structure" Journal of Finance, 28:911-921.

Korkmaz, T., Başaran, Ü. ve Gökbulut, R.İ. (2009) “İMKB'de İşlem Gören Otomotiv ve Otomotiv Yan Sanayi İşletmelerinin Sermaye Yapısı Kararlarını Etkileyen Faktörler: Panel Veri Analizi” İktisat İsletme ve Finans, 24(277):29-60.

Kim, E. (1978) "A Mean-Variance Theory of Optimal Capital Structure and Corporate DebtCapacity" Journal of Finance, 33:45-63.

Leland, H. ve Pyle, D. (1977) "Information Asymmetrics, Financial Structure, and Financial Intermediation" Journal of Finance, 32:371-388.

Miller, M.(1977) "Debt and Taxes" Journal of Finance, 32:2.

Modigliani, F. ve Miller, M. (1958) "The Cost of Capital, Corporation Finance and the Theory of Investment" American Economic Review, 48: 261-297.

Modigliani, F. ve Miller, M. (1963) "Corporate Income Taxes and the Cost of Capital: A Correction" The American Economic Review, 53(3):433-443.

Myers, S.C. (1984) "The Capital Structure Puzzle" Journal of Finance, 39:575-592.

Myers, S.C. ve Majluf, N.S. (1984) "Corporate Financing and Investment Decisions When Firms Have Information That Investors Do Not Have" NBER Working Paper Series, No: 1396.

Okuyan, H.A.ve Taşçı, H.M. (2010) "Sermaye Yapısının Belirleyicileri: Türkiye'deki en Büyük 1000 Sanayi İsletmesinde Bir Uygulama” BDDK Bankacılık ve Finansal Piyasalar Dergisi, 4(1):105-120.

Özkan, A. (2001) "Determinants of Capital Structure and Adjustment to Long Run Target: Evidence from UK Company Panel Data" Journal of Business Finance and Accounting, 28(1-2): 175-198.

Pandey, I. (2001) "Capital Structure and the Firm Characteristics: Evidence from an Emerging Market" IIMA Working Paper Series, No:10-04.

Pozdena, R. J. (1987) "Tax Policy and Corporate Capital Structure” Economic Review, 4: 37-50.

Prasad, S., Green, C. ve Murinde, V. (2003) "Company Financial Structures in Developing Economies: Evidence from a Comparative Analysis of Thai and Malay Companies" University of Birmingham Working Paper Series.
Rajan, R.G. ve Zingales, L. (1995) "What Do We Know About Capital Structure? Some Evidence From International Data” Journal of Financial Economics, 51: 1421-1460.

Ross, S. (1977) "The Determination of Financial Structure: The Incentive-Signaling Approach" Bell Journal of Economics, 8: 23-40.

Sayılgan, G., Karabacak, H. ve Küçükkocaoğlu, G. (2006) "The Firm-Specific Determinants of Corporate Capital Structure: Evidence From Turkish Panel Data" Investment Management and Financial Innovations, 3(3):125-139.

Sogorb-Mira, F. (2002) "How SME Uniqueness Affects Capital Structure: Evidence From A 1994-1998 Swidish Data Panel" Small Business Economics, 25(5):447-457.

Stiglitz, J.E. (1988) "Why Financial Structure Matters?" Journal of Economic Perspectives, 2(4): 121-126.

Stulz, R. (1990) "Managerial Discretion and Optimal Financing Policies" Journal of Financial Economics, 26:327.

Taggart, R.A. (1977) "A Model of Corporate Financing Decisions" Journal of Finance, 32: 1467-1484.

Teker, D., Taşseven, Ö. ve Tükel, A. (2009) “Determinants of Capital Structure for Turkish Firms: A Panel Data Analysis" International Research Journal of Finance and Economics, 29:179-187.

Terim, B. ve Kayalı, C.A. (2009) "Sermaye Yapısını Belirleyici Etmenler: Türkiye'de İmalat Sanayi Örneği” Celal Bayar Üniversitesi Sosyal BilimlerEnstitüsü Dergisi, 7(1): 125-154.

Titman, S. ve R. Wessels (1988) "The Determinants of Capital Structure Choice" Journal ofFinance, 43(1):1-19.

Topal, Y. (2006) “IMMKB’ye Kayıtlı İşletmelerin Sermaye Yapıları ve Finansal Kaldıraç Oranlarının Kârlılıklarına Etkisi” Erciyes Üniversitesi İktisad İdari Bilimler Fakültesi. Dergisi, 27:45-70.

Yener, A.L. (2002) "Türk Firmalarının Sermaye Yapısını Etkileyen Faktörler: Beşyüz Firmadan Hisse Senetleri İMKB'de İşlem Görenler İçin Bir Analiz" Yayınlanmamış Doktora Tezi, Ankara, Ankara Üniversitesi Sosyal Bilimler Enstitüsü.

Yükeri, Y. (2009) "İmalat Sanayi İşletmelerinin Sermaye Yapısı Kararlarını Etkileyen Faktörlerin İncelenmesi: Adana Hacı Sabancı Organize Sanayi Bölgesi'nde bir Uygulama” Yayınlanmamış Yüksek Lisans Tezi, Adana, Çukurova Üniversitesi Sosyal Bilimler Enstitüsü.

Kamuyu Aydınlatma Platformu, www.kap.gov.tr. 


\section{EKLER}

Ek 1: Korelasyon Matrisleri

\begin{tabular}{|c|c|c|c|c|c|c|c|c|c|}
\hline & $B$ & UVB & $\mathrm{AK}$ & ATO & BDVK & $A B$ & BYM & ÖK & VY \\
\hline \multicolumn{10}{|c|}{ Panel A. Çimento } \\
\hline$B$ & 1.0000 & & & & & & & & \\
\hline UVB & 0.5775 & 1.0000 & & & & & & & \\
\hline AK & -0.3082 & -0.1115 & 1.0000 & & & & & & \\
\hline ATO & -0.6859 & -0.3944 & 0.2099 & 1.0000 & & & & & \\
\hline BDVK & 0.2398 & 0.1616 & -0.4628 & -0.1100 & 1.0000 & & & & \\
\hline$A B$ & 0.3205 & 0.5381 & 0.1306 & -0.5353 & -0.0640 & 1.0000 & & & \\
\hline BYM & 0.1447 & 0.0967 & 0.3223 & -0.2245 & -0.1039 & 0.1553 & 1.0000 & & \\
\hline ÖK & -0.4002 & -0.1854 & 0.9525 & 0.2211 & -0.5018 & 0.1141 & 0.2880 & 1.0000 & \\
\hline VY & -0.0144 & 0.3052 & -0.3648 & 0.0526 & 0.4334 & -0.0866 & -0.2643 & -0.3967 & 1.0000 \\
\hline \multicolumn{10}{|c|}{$\begin{array}{l}\text { Panel B. } \\
\text { Otomotiv }\end{array}$} \\
\hline B & 1.0000 & & & & & & & & \\
\hline UVB & 0.3903 & 1.0000 & & & & & & & \\
\hline AK & -0.3757 & -0.0161 & 1.0000 & & & & & & \\
\hline ATO & -0.5922 & -0.2840 & 0.6359 & 1.0000 & & & & & \\
\hline BDVK & 0.1377 & 0.3237 & -0.0431 & -0.0452 & 1.0000 & & & & \\
\hline$A B$ & 0.2619 & 0.6956 & 0.1598 & -0.1345 & 0.3764 & 1.0000 & & & \\
\hline BYM & 0.1051 & 0.1967 & 0.2328 & -0.1167 & 0.0064 & 0.0302 & 1.0000 & & \\
\hline ÖK & -0.3366 & 0.2311 & 0.6538 & 0.2823 & 0.0415 & 0.3005 & 0.2459 & 1.0000 & \\
\hline VY & 0.0937 & 0.0960 & -0.2359 & -0.3205 & -0.0027 & -0.0291 & -0.2746 & -0.3246 & 1.0000 \\
\hline \multicolumn{10}{|c|}{ Panel C. Bilişim } \\
\hline$B$ & 1.0000 & & & & & & & & \\
\hline UVB & 0.1469 & 1.0000 & & & & & & & \\
\hline $\mathrm{AK}$ & 0.2053 & -0.1255 & 1.0000 & & & & & & \\
\hline ATO & -0.5785 & 0.0446 & 0.2607 & 1.0000 & & & & & \\
\hline BDVK & -0.6552 & -0.0224 & -0.3072 & 0.2763 & 1.0000 & & & & \\
\hline$A B$ & 0.4691 & 0.1238 & 0.1730 & -0.3392 & -0.4536 & 1.0000 & & & \\
\hline BYM & 0.1373 & -0.0363 & 0.0348 & -0.0732 & -0.0896 & -0.0241 & 1.0000 & & \\
\hline ÖK & 0.0371 & -0.5370 & 0.7570 & 0.2307 & -0.1557 & 0.1163 & 0.0056 & 1.0000 & \\
\hline VY & -0.8035 & 0.0790 & -0.4931 & 0.3502 & 0.5795 & -0.2450 & -0.0839 & -0.2859 & 1.0000 \\
\hline
\end{tabular}

Ek 2:Otokorelasyon Testi Bulguları

\begin{tabular}{|c|c|c|c|c|}
\hline & Katsayı & Standart Hata & t-istatistiği & P-değeri \\
\hline Panel A. Çimento & & & & \\
\hline D(Resid01) & 0,5046 & 0,0588 & 8,5689 & $\mathbf{0 , 0 0 0 0}$ \\
\hline F-istatistiği & $\mathbf{2 4 , 8 6 0 3}$ & & & \\
\hline Panel B. Otomotiv & & & & \\
\hline D(Resid01) & 0,4202 & 0,0635 & 6,6169 & $\mathbf{0 , 0 0 0 0}$ \\
\hline F-istatistiği & $\mathbf{5 , 3 2 1 6}$ & & & \\
\hline Panel C. Bilişim & & & & \\
\hline D(Resid01) & 0,5078 & 0,0497 & 10,2071 & $\mathbf{0 , 0 0 0 0}$ \\
\hline F-istatistiği & $\mathbf{3 1 , 0 5 8 7}$ & & & \\
\hline
\end{tabular}


Ek 3:Farklı Varyanslılık Testi İstatistikleri

\begin{tabular}{|l|c|c|c|c|c|c|c|}
\hline & & & & & & & \\
\hline Panel A. Çimento & Sabit & AK & D(ATO) & D(AB) & BYM & D(VY) & D(BDVK) \\
\hline Katsayı & 0.0023 & -0.0014 & 0.0002 & -0.0932 & -0.0010 & 0.0013 & -0.0561 \\
\hline Standart Hata & $(0.0006)$ & $(0.0051)$ & $(0.0003)$ & $(0.0895)$ & $(0.0039)$ & $(0.0114)$ & $(0.0751)$ \\
\hline P-değeri & {$[0.0010]$} & {$[\mathbf{0 . 7 7 7 2}]$} & {$[\mathbf{0 . 4 6 6 0}]$} & {$[\mathbf{0 . 3 0 2 3}]$} & {$[\mathbf{0 . 7 9 3 9 ]}$} & {$[\mathbf{0 . 9 0 7 2 ]}$} & {$[\mathbf{0 . 4 5 8 2}]$} \\
\hline F-istatistiği & 0.4193 & & & & & & \\
\hline P-değeri(F-ist) & {$[\mathbf{0 . 8 6 2 9 ]}$} & & & & & & \\
\hline Panel B. Otomotiv & Sabit & D(AK) & D(ATO) & AB & BYM & VY & BDVK \\
\hline Katsayı & 0.0028 & 0.0047 & -0.0002 & 0.0087 & -0.0027 & 0.0016 & -0.0148 \\
\hline Standart Hata & $(0.0018)$ & $(0.0102)$ & $(0.0002)$ & $(0.0073)$ & $(0.0029)$ & $(0.0052)$ & $(0.0095)$ \\
\hline P-değeri & {$[0.1249]$} & {$[\mathbf{0 . 6 4 4 7}]$} & {$[\mathbf{0 . 4 0 8 9}]$} & {$[\mathbf{0 . 2 4 3 4}]$} & {$[\mathbf{0 . 3 6 3 0 ]}$} & {$[\mathbf{0 . 7 5 5 6}]$} & {$[\mathbf{0 . 1 2 5 2}]$} \\
\hline F-istatistiği & 0.8671 & & & & & & \\
\hline P-değeri(F-ist) & {$[\mathbf{0 . 5 6 0 0 ]}$} & & & & & & \\
\hline Panel C. Bilişim & Sabit & D(AK) & D(ATO) & D(AB) & BYM & D(VY) & D(BDVK) \\
\hline Katsayı & 0.0046 & 0.0088 & -0.0001 & -0.0408 & 0.0011 & 0.0201 & -0.0301 \\
\hline Standart Hata & $(0.0013)$ & $(0.0184)$ & $(0.0007)$ & $(0.0670)$ & $(0.0011)$ & $(0.0158)$ & $(0.0875)$ \\
\hline P-değeri & {$[0.0016]$} & {$[\mathbf{0 . 6 3 4 2 ]}$} & {$[\mathbf{0 . 8 1 1 7 ]}$} & {$[\mathbf{0 . 5 4 5 7 ]}$} & {$[\mathbf{0 . 3 4 1 3}]$} & {$[\mathbf{0 . 2 1 0 6}]$} & {$[\mathbf{0 . 7 2 3 6}]$} \\
\hline F-istatistiği & 0.7866 & & & & & & \\
\hline P-değeri(F-ist) & {$[\mathbf{0 . 6 2 9 9}]$} & & & & & & \\
\hline
\end{tabular}

